\title{
SOCIAL NETWORKS AND INTERNATIONAL RELATIONS IN THE TOURISM SECTOR
}

\section{DAVID CALDEVILLA-DOMÍNGUEZ}

davidcaldevilla@ccinf.ucm.es Graduate and Doctor in Information Sciences. Graduate in Teaching. Lecturer in the Faculty of Information Sciences at the UCM (Spain). Lecturer at: U. Complutense, U. Europea de Madrid, IED, ESERP and IPAM. Index $\mathrm{h}$ 17. 6th Spanish author in published works, 13th in cited articles and 20th in citations received out of 747 authors. Secretary General of the Spanish Society for Ibero-American Communication Studies and of the International Forum on Communication and Public Relations.

\begin{abstract}
ALMUDENA BARRIENTOS-BÁEZ
almudena.barrientosbaez@unir.net $\mathrm{PhD}$ with international mention in Education and lecturer at the Univ. Europea and the Univ. Internacional de La Rioja (Spain). Master in Protocol Management, Production, Organization and Design of Events, area of Communication and Master in Tourism Accommodation Management. Degree in Tourism and Teaching. She is part of the project new values, governance, financing and public audiovisual services for the Internet society:

European and Spanish contrasts (RTI2018-096065-B-I00) of research of the State Programme of R+D+I.
\end{abstract}

\section{JUAN ENRIQUE GONZÁLVEZ-VALLÉS} jegonzalvez@ucm.es

$\mathrm{PhD}$ in Information Sciences and Degree in Journalism. He is a member of the Department of Theories and Analysis of the Department of Communication at the Complutense University of Madrid (Spain). He is a member of the Concilium Research Group as well as of the Spanish Society of Ibero-American Communication Studies and Forum XXI. He was director of the International University Congress on Communication: Contents, Research, Innovation and Teaching, and is currently a member of its Organizing Committee and Scientific Committee.

MANUEL BLANCO-PÉREZ mblancoperez@us.es

Doctor in Communication and Literature. Master in Communication and Culture, University of Seville. Master in Social Economy. He is currently a lecturer in the Department of Marketing and Communication at the University of Cadiz (Spain) and in Journalism at the University of Seville.

\section{Abstract}

Tourism is a social and scientific phenomenon. From here, its knowledge must be approached from a complete vision and not limited to a single discipline or set of them separately, since it is multidisciplinary. The role of international relations in tourism is a phenomenon with great economic, social, cultural, and environmental consequences, which can condition the behavior of tourists and the tourism sector as a whole. The pandemic caused by COVID-19 has affected the entire world population, the main economic engines of each and every one of the countries and international relations derived from the tourism sector. The coronavirus has not only affected the people who are under its effects, but it has also changed the global perception of reality just as the media have been forced to create a new way of communicating. Meanwhile, social networks have been the fastest and easiest way to disseminate all kinds of information and misinformation, adopting new formats and new anti-hoax measures (fake news). They have been effective and it is identified that thanks to the different platforms, citizens have found themselves somewhat more sheltered, understood and have received information about what is happening around their lives. Due to the closure of borders and the decrease in flights, worldwide tourism suffers serious consequences and for all this, the incidence of the coronavirus in the economy and international relations are protagonists of a difficult reality and a prompt and expected recovery.

\section{Keywords}

Comunicación; Turismo; Redes sociales; Relaciones internacionales; Covid-19.

\section{How to cite this article}

Caldevilla-Domínguez, David; Barrientos-Báez, Almudena; Gonzálvez-Vallés, Juan Enrique; Blanco-Pérez, Manuel. Social networks and international relations in the tourism sector. Thematic dossier International Relations and Social Networks, July 2021. Consulted [online] on date of last visit, https://doi.org/10.26619/1647-7251.DT21.13

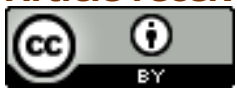




\title{
SOCIAL NETWORKS AND INTERNATIONAL RELATIONS IN THE TOURISM SECTOR ${ }^{1}$
}

\author{
DAVID CALDEVILLA-DOMÍNGUEZ
}

ALMUDENA BARRIENTOS-BÁEZ

JUAN ENRIQUE GONZÁLVEZ-VALLÉS

MANUEL BLANCO-PÉREZ

\section{Introduction}

Tourism can be addressed in a multispectral way, from its social aspects, its cultural importance, its impact on the natural environment, and, of course, its economic strand (Caldevilla-Domínguez et al., 2020). It is not even limited to be seen as an industry of the tertiary and free time sector, and tourism is the result of public and private, and governmental and popular actions. In spite of that, there is limited academic action regarding this field, thus leading to an analytical gap in the subject and its link to International Relations. Such gap can be filled with the multidisciplinary contribution derived from the study of local and/or national tourism, including its economic, cultural, and other strands, as a differentiating attractive aspect (Martínez-Rolán et al., 2019).

There is also the gap linked to the influence of information and communications technologies (ICTs): since through their implementation in the tourism sphere, users with intermediate digital competences (Fernández-Cavia et al., 2020, ChinchayVillarreyes et al., 2020) are influencing the industry, specifically by endorsing products or services via social networks (Matassi \& Boczkowski, 2020). In the current digital context, relation ambits, which a priori have opposite origins, are linked (GangaContreras et al., 2017), anticipating the multidisciplinarity climate that should characterize tourism research: The participatory culture of prosuming (Martín-Antoranz et al., 2020) imposed by ICTs environment (ultimately, the Web is strongly related to various forms of consumption (Gonzálvez-Vallés et al., 2020), the tourism industry and the International Relations linked to it. In the first one, there are practices like crucibles, the collective intelligence and the collaborative culture between users and threats such as the ones pointed out by Cáceres (2009) and Barrientos-Báez et al. (2018), while the second promotes the homogenization of productive processes, sacralizing profits and

1 Article translated by Carlos Javier Rivas Quintero (University of the Andes, Mérida, Venezuela). 
business concentration. The third is the maximization of the human relation science, expressed in its terms of greatest volume and consequences, but also more influenced by micro-managing. Between these three subjects of study there is a gray area. It is here where users with intermediate digital competences are influencing tourism industries, specifically by endorsing products or services via social networks (Matassi and Boczkowski, 2020, Araújo and González, 2019).

This work partially emerges from reflections on the new media ecosystem and its relation with one science field -the study of the tourism phenomenon- which has a component in and impact on International Relations.

In tourism science, the emergence of social networks changed the communicative paradigm (Caldevilla-Domínguez, 2014), transforming how people from all the countries and social classes access information, plan, and share their trips, allowing suppliers to interact dynamically and directly with users, thus facilitating the adaptation of their activity to the new realities with the implementation of effective feedback. However, various studies show there is still a lack of knowledge of how some initiatives can lead to a better use of social networks (Oliveira et al., 2017, Hays et al., 2013, Infante-Limón, 2014). Social networks gain strength from specific environments (Calderón et al., 2017).

This article aims to contribute to a better understanding of social networks' potential in tourism and tourism's relation with International Relations.

\section{Design and Method}

This article is a narrative review aimed to search and retrieve documents concerning the implementation of ICTs in tourism promotion and tourism activities that can be linked to International Relations, to respond to the initial statement. To this end, various sources from relevant subjects have been consulted in books, articles, studies, and scientific journals. Criteria for information searching included: studies, articles, and monographs published until 2020, in Spanish or English, with open access to the full text (with the possibility of giving way to older material if it provided a relevant theoretical basis). The exclusion criteria included articles that were markedly opposite to a scientific source, such as opinion articles, or computer access material produced by users without being grounded in expertise. The search strategy was based on tourism, International Relations, and ICTs descriptors, relevant to the subject of study.

\section{Development}

\subsection{Tourism}

As a phenomenon, it can be affirmed that tourism has elements and manifestations prior to its generalization and recognition as a proper economic sector: having produced business branches very open to asymmetric communication (Navarro Celis et al., 2020), such as cultural tourism (Araújo and Domínguez, 2012), or entering the thriving sustainability market (Barrientos-Báez et al., 2020a, León-León et al., 2018). 
The implementation of tourism science with pecuniary purposes to reality has generated these branches, thus responding to a variety of audiences segmented by economic criteria (Caldevilla-Domínguez et al., 2019). Due to these factors, tourism phenomenon is studied multilaterally, resulting in investigative subsections such as tourism psychology, tourism politics, tourism economy, and tourism sociology, as means to determine the segments and different types of demand and target audiences.

All this makes it impossible for the definition of tourism to be limited to its economic strand. A reductionist vision of the tourism theory only to leisure time underpinned by the fact that tourism requires its practitioners to have time and means to travel, driven by their searching for entertainment, being these conditioning factors necessary but insufficient for the study of the tourism social phenomenon.

In 1991, The International Conference on Travel and Tourism Statistics, approved by UNWTO (World Tourism Organization), signified the zenith of research efforts in the subject between 1975 and 1985, from both international organizations and interested countries, with Canada standing out. Basing on previous studies, WTO defined internal and international tourism, creating a classification of tourism activities. The basic definition was, "the activities of persons traveling to and staying in places outside their usual environment for not more than one consecutive year for leisure, business and other purposes not related to the exercise of an activity remunerated from within the place visited (WTO, 1991). Furthermore, Goeldner (2000) defines it as "the processes, activities, and outcomes arising from the relationships and the interactions among tourists, tourism suppliers, host governments, host communities, and surrounding environments that are involved in the attracting and hosting of visitors". His approach limits the scope of analysis to the perspective from the country source of tourists, the relationships among them and the business entities providing services to them.

Regarding its characteristics, the tourism product is mainly "time" for sightseeing, staying in hotels, and travelling. It is also the product of "seasons", since certain dates increase the value of territories (Fernández-Paradas and Sánchez Guzmán, 2018). These time choices entail a "life section" that is different, enjoyable, and of a leisure or work nature, based on the enjoyment of experiences in places outside or different from people's usual environment. Like any other service, it is intangible and subjective from both sides of the service chain. The objective is to make the client feel sensations and emotions through new experiences; with the purpose of achieving that feeling of living something new, which is why it is essential for the business, and the Academy, to train those in charge of providing these experiences (Barrientos-Báez et al., 2020b). It is not about offering people material goods but creating and meeting their expectations of the experiences awaiting them, the environment they will experience and the memories they will cherish. Especially, the unique selling proposition is satisfying the expectations that people were helped to generate. Using tangible goods is an essential part of the process to create the expectations the client seeks to experience such as those involved in transportation, the food available for visitors, accommodation amenities, and a very relevant aspect recently, the safety of the trip, which all combined determines the quality of the service enjoyed by the traveller. Now more than ever, the market is governed by clients' public opinions (Feijoo-Fernández and Guerreo-Cortés, 2018). Other characteristics of the tourism product that influence service quality are: 
- Expiration: the inability of stocking a service. Service time: either you use it or lose it.

- Aggregability and modularity: tourism product is formed by "mixing" diverse "ingredients", some of which can be replaced with other equal or similar ones.

- Subjectivity, individuality, and immediacy: it is subjective since it depends on clients and suppliers' circumstances at the time of the tourism experience taking place. Based on such circumstances, the level and type of satisfaction will vary from one client to another.

- Production-consumption simultaneity: the client participates in finishing the product and is part of its final result.

- Heterogeneity: the product is made up of a myriad of factors, many of which are not foreseeable or programmable, thus the experience is never exactly the same; for example, due to the aforementioned simultaneity.

- It is not transportable: the client is transported, not the product.

- Seasonality: subject to fluctuations in demand due to the general and specific weather conditions.

- Interdependence: with the rest of its sector and related economic areas.

- Easily copied: it is extremely easy for anyone to gain a deep understanding of the product.

- High fixed costs: the necessary infrastructure to provide the service has to be constantly maintained in proper conditions, regardless of whether they are being used.

Therefore, we can affirm that the constituent parts of tourism are affected by the very occurrences and types of relationships that cause and surround trips: among visitors and entities managing these trips, service suppliers that allow and fill with content tourists' stay, and legislation applicable in the origin, destination and internationally.

\subsubsection{Travellers}

WTO has an essential glossary that defines traveller as "someone who moves between different geographic locations, for any purpose and any duration." The terms of international tourism that we have used here are defined by WTO (1991) as follows:

- Visitor: a traveller taking a trip to a main destination outside his/her usual environment, for less than a year, for any main purpose other than to be employed by a resident entity in the country or place visited.

- Tourist: A visitor who travels to a country other than that in which he/she has his/her usual residence for at least one night but not more than one year, and whose main purpose of visit is other than the exercise of an activity remunerated from within the country visited.

- Excursionist: a visitor who travels to a country other than that in which he/she has his/her usual residence and that is outside his/her usual environment, for less than 24 hours without spending the night in the country visited. His/her main purpose of visit is other than the exercise of an activity remunerated from within the country visited. 


\subsubsection{Analysis of tourism multidisciplinarity}

The different definitions of current tourism are product of constituent principles from various disciplines.

Precisely, the diversity of conceptual approaches concerning tourism has represented an obstacle to the creation of a comprehensible theoretical framework to understand and classify the issues regarding this subject. From economy, sociology, and tourism, there have only been discussions on the economic strand and the sociocultural impact. This is due to the preconception that scholars of this phenomenon have tools from other disciplines to understand it. But this leaves very little room to determine what tourism per se has to say, as a scientific discipline, about itself as such phenomenon. Studying tourism from this angle entails acknowledging it has innated means of analysis in those subjects that are inherent to it. However, as aforementioned, its scholars rely on a treasure of theories and methods that originated from various other disciplines of social sciences: politics, sociology, anthropology, psychology, ecology, geography, economy, history, etc., which are fields of study pertaining to other subjects (Tribe, 1997), and that are somewhat related to tourism: such as marketing, administration, leisure, and entertainment, directly linkable to the use of social networks (Parra-López et al., 2014). Although tourism touches various facets of human life, the economic and commercial aspects have received a favorable treatment in this sense: probably because they have constituted a resource for the development of third world countries. A money-making machine in many economies. This preconception has sometimes become a reality, while in other cases is still no more than a false promise (Fiorello, 2010; Boccardi et al., 2008). This has caused the field of economy to be the one in charge of generating the largest quantity of applicable theoretical-conceptual contributions. Tourism's socioanthropological aspects, which we have also mentioned already, have not been immune to all this, causing terms related to "subject of tourism", "role" or "actor" of tourism, etc., to be coined. This multidisciplinary intervention in tourism-subject has promoted the emergence of the concepts of tourism geography, tourism psychology, tourism policy, or tourism legislation. The qualifier tourism operates, in this case, as the nexus that connects tourism, geography, and psychology; disciplines that are not epistemologically related to tourism, but which have had an enormous impact on the initial conception of professionals in the sector. The noun-adjective tourism must allude to what the whole name represents, and not partially linked realities. Tourism is a complex and human phenomenon (Tribe, 1997); hence it needs the participation of the aforementioned disciplines: not only in an aggregative sense, but also in a way that all the disciplines involved can benefit from the total contribution. Tourism is a phenomenon that extends to various sectors of human existence, individually and socially: if tourism has favorable financial effects upon an area, it would also influence, in one way or another, the social aspect. Hence, the participation of economy and sociology will be necessary to study its effects and characteristics. Therefore, it is essential to note how important the economic, social, political, and environmental configurations are in the creation of tourism's theoretical corpus: acknowledging that, in accordance with the context surrounding this phenomenon, it must be subject of a comprehensive study including all the applicable disciplines. 
Acknowledging tourism as a subject of a multidisciplinary study must not entail that they would "confiscate" said subject and, with it, the exclusivity on knowledge regarding this matter. The sense of education in tourism is to understand, explain, and substantiate tourism knowledge, but as stated before, from a comprehensive and truly multidisciplinary perspective. All this without falling, to the extent possible, in partisan preconceptions associated to these multiple disciplines that, consciously or unconsciously, could hinder the ultimate goal of multidisciplinarity. Tourism's scholars must not limit themselves to the particular approaches of their fields but use the appropriate contributions of each discipline in a way that the subject under discussion (tourism) can be reformulated. This interdisciplinarity, of which we are constantly speaking, gets very close to the concept of hybridization: aiming that this subject cease to be supported only by a few chairs that are erected in "the" theoretical framework of tourism. These special academic needs derive from tourism being, in its origin, a subject of study essentially human, whose activity spectrum permeates diverse layers of the aforementioned humanity. These factors result in the necessity of disciplinary convergence in each one of these layers that allow forming an understandable applicable whole: to address aspects derived from free time, consumption, social trends and cultural context, individual motivations and views, as well as the very context of tourism activity. With the latter taking care of its policies, business models, and how they influence their social environments, its development regarding globalization, sociocultural characteristics, and the adaptation processes to the modernity of tourist destinations. To this end, the creation of conceptual-theoretical schemes that define the subject of study, called "tourism", are necessary. It should not receive the tittle of science merely for its theoretical and practical framework combination, nor should its study be limited to an epistemological question, nor should it be proposed that it be limited to being an ordinary subject field exclusively oriented toward the execution of the activity and its ramifications in International Relations, since the main problem it faces is not only its development as business, but how to understand it and redirect it as an undisputed reality, aiming at the comprehensive development of destination countries and serving as a positive nexus to unite nations.

\subsection{International Relations}

They were initially conceived in an entirely historical-political light, but have increasingly taken into consideration the economic, cultural, and social components in recent times. After all, the science of International Relations addresses social relations, whether these are the relations that originate among individuals, groups of individuals or both, with the preeminence it gives to the relations between States. There is consensus (WTO, 1991) that International Relations address a living part of social reality, which makes them a social science. Arenal (1990) states, "International Relations are configured as an integration and synthesis discipline of the data provided by other disciplines, while the objective of its research provides superior content, which grants its special character to it at the core of social sciences," implying that International Relations are not limited to the relations between States, extending to the interactions between people and groups located in different countries; relations between groups internationally, and not only between governments. 


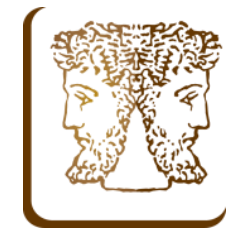

This perspective is relevant since practice has demonstrated the necessity to understand international events in essence, thus allowing attaining categorizations of the expectable or predictable behavior in International Relations. Some authors argue that International Relations must be studied as a specialized branch of political science, disregarding the study of other non-strictly political actors and areas, for example, the geographic constraints, the ideological phenomena, NGO, the state of public opinion, etc. Although they have certainly been considered a part of political science, now their interdisciplinary, multidisciplinary and transdisciplinary character tends to be highlighted.

The scope of International Relations encompasses International Political Economy, Law, Philosophy, Geopolitics, Sociology, Anthropology, Psychology, and of course, Tourism: with particular emphasis on the analysis and materialization of Groups-State foreign policy. Rodríguez-Torres and Puerta-Rodríguez (n.d.) state, "Hence, International Economic Relations are defined as the extension of national economic relations to the outside, which becomes a clear manifestation of its nature as Social Relations of Production" (p. 8). And "we must also consider that these Relations are directly influenced by the political relations that entail the existence of different States, hence they will also depend on the domestic and foreign economic policy implemented by countries, constrained at their basis by the different development levels of participants' productive forces" (p. 9). It is possible to affirm that economic relations on an international scale, based on their complex and multispectral nature and based on the sector in which they develop, are five: commercial, monetary, financial, collaborative/cooperative, and for economic integration. González-Gómez (1990) states "[...] the discipline of international relations emerges to satisfy the need of popular masses, on the one hand of governments, and on the other, to understand the complicated current international panorama $[\ldots]$, therefore, the discipline begins as a science of great powers and to serve their interests, although in fact it is of interest to all the nations in the world" (p. 3). Foresight studies of International Relations aim to support the decision-making processes that enhance the most positive developments of the international scene, minimizing the negative ones. International Relations, being a science, are not a normative science: their purpose is not establishing behavioral norms or principles of the actors involved or individuals per se, being the economic strand important.

\subsection{Applied ICTs}

According to Araújo and Domínguez (2012) the key to an effective digital communication lies in "searching ways of managing it and making it attractive to users", geared towards generating the need of consuming the product. Tourism is probably one of the activities that have been influenced the most by Information and Communications Technologies (Altamirano et al., 2016) after teaching with regard to its previous establishment (Correyero, 2003). The action of new digital communication technologies permeates the very existence of travel thanks to the modern Orwellian telescreens: mobile devices with geolocation applications capable of assisting travellers with vital or minor aspects. Social networks affect how advertisements are perceived, by facilitating the contrast between the experience being advertised and the impression of thousands of travellers (MartínezSala et al., 2019). Therefore, we can affirm that the traditional ways of obtaining information (and even of advertising) have been left behind, with the risks that hoaxes 


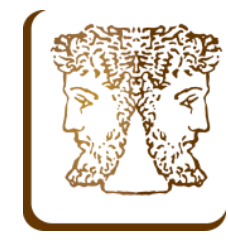

entail, a blight on certain economic sectors such the hospitality industry (and certainly tourism) since sources must be compared and that is hardly ever made (Ruiz Rico, 2020).

The tourist 2.0 is an independent and technologically capable tourist promoter, since they rely on a collaborative digital community (Sarmiento \& Terceño, 2018). Social networks are an ideal space to research the market and delve into the particularities of users, especially of digital native adults, from 18 to 30 years of age. "Knowing the personality of others is an essential ability to have successful relationships" (Martínez-Valerio, 2016), and within this digital communication context, social networks emerge like an open-door platform leading to the inner minds of these generations. The daily number of trends that appear on social networks from which brands could benefit is innumerable; but they must be assessed professionally to determine which ones concern their audiences and specific market niches. Tourism sector has made used of the Web 2.0, and especially, of social networks, making them promotional tools in everyday life, leading to the emergence of specific social networks for this sector: virtual communities launched by users. For any tourism institution or company, it is indispensable to know how to operate within the social networks environment to relate better with its users or potential travellers.

\section{Results}

The importance of tourism in International Relations is mainly perceived in how these disciplines are interrelated: something noticeable in the systemic approach and in the elements that are inherent to tourism: its multidisciplinary, aggregative, dynamic, and open nature.

The systemic approach is the most appropriate one to understand this "tourism system" for several reasons: first, because it highlights the interdependence in tourism; various relevant disciplines working towards achieving a common goal. There is also the open nature of tourism as a system, having a flexible, dynamic, and changing structure. New concepts and facts are constantly being implemented to tourism. Additionally, it is affected by multiple external influences leading to both negative and positive results on any subject that enters its contact sphere. It is also important to bear in mind the complexity and variety of the tourism discipline as seen in the varied offer of travel packages and types of tourism, and as it can be seen in the intense competitiveness within the sector, including the big companies worldwide.

The way how the COVID-19 phenomenon has boosted the implementation of ICTs and the even greater growth of Social Networks has generated the acceleration in this systemic interrelation: thus, enhancing tourism user communities (internationally crosscutting communities, with English increasingly becoming the lingua franca) despite the logical recent decline in the king-strand concerning the study of tourism: the economic strand.

Therefore, at an international level, there have been digital exchanges of information in the tourism area, and it has been possible thanks to social networks. Due to them, a portion of the current pre-COVID international relations has permitted this relation subsphere in the tourism sector to keep on functioning despite the circumstances, promoting interest, demand, and information for the future. Here lies the importance of international 
relations for the tourism discipline, as well as part of the added value provided by global digitalization to it.

\section{Conclusions}

The international nature of social relations is undeniable, regardless of whom their protagonists are and whether they take place within a State or, on the contrary, by breaking its limits. We are speaking of relationships among nations, groups, cities: between groups and individuals, and between individuals: being tourism a paradigmatic example of International Relations not directly linked to States of big groups. International Relations as a science, aim to support the decision-making processes that enhance the most positive developments of the international scene, minimizing the negative ones. They are not a normative science (but a science after all) since their purpose is not establishing behavioral norms or principles of the actors involved or individuals per se, being the economic strand important.

Meanwhile, tourism is both a newly developed social phenomenon and a science regarding how it must be studied and treated academically. Thus, knowledge here must be attained through a real multifaceted approach, without falling in preconceptions derived from a single field of knowledge; something that is much more effectively achieved with a systemic approach that allows perceiving how this phenomenon is related to the rest of reality and sciences. It should not receive the tittle of science merely for its theoretical and practical framework combination, nor should it be limited to an epistemological question, nor should it be an ordinary subject field exclusively oriented toward the practical ambit and its ramifications in International Relations, since the main problem it faces is not only its development as business, but how to understand it and redirect it as an undisputed reality, aiming at the comprehensive development of destination countries and serving as a positive nexus to unite nations.

The role of International Relations within this phenomenon and the tourism discipline bears a significant economic and social weight, although the current situation of the tourism-economic activity being at a standstill due to COVID-19 offers the unique opportunity of studying this phenomenon with relative independence from this variable.

Tourists 2.0 are now active subjects of the communicative process at an international level in the tourism industry: beyond their traditional importance as "clients", their "digital" role now is to be advertisers, promoters, and critics of the products they consume, and the services being offered to them.

This change of paradigm regarding their inner "I" entails the need of rethinking the communication strategies based on the new digital environment, given the fact that the new publics in the sectors are native of it, and have created their own collaborative communities in it; communities capable of removing a large portion of the reputational control from the hands of companies, and to keep operating and exercising their influence during times of recession in the sector. 


\section{References}

Altamirano Benítez, V.; Túñez-López, J., \& Valarezo-González, K. (2016). Promoción turística 2.0. Análisis de las redes sociales de los gobiernos iberoamericanos. Opción, $32(9), 32-53$.

Álvarez-Sousa, A. (2005). La contribución del turismo al desarrollo integral de las sociedades receptoras. Aspectos teórico-metodológicos. Revista Política y Sociedad, 42(1), 57-84.

Araújo Vila, N., \& Domínguez Vila, T. (2012). Los festivales de cine como elemento potenciador de destinos turísticos. El caso de San Sebastián. Revista de Comunicación Vivat Academia, 121, 31-49. http://dx.doi.org/10.15178/va.2012.121.31-49

Araújo Vila, N., \& Domínguez Vila, T. (2014). Gestión de las Redes sociales turísticas en la web 2.0. Revista de Comunicación Vivat Academia, 129, 57-78. https://doi.org/10.15178/va.2014.129.57-78

Araújo, C., \& González-Valiente, C. (2019). Hacia un pensamiento informacional iberoamericano. Bibliotecas. Anales de Investigación, 15(2), 137-139.

Arenal, C. (1990). Introducción a las Relaciones Internacionales. Madrid: Editorial Tecnos.

Barrientos-Báez, A., Barquero-Cabrero, M., \& García-García, E. (2018). Posverdad y comunicación 2.0: el reto periodístico de una era sin periodistas. Revista de Ciencias de la Comunicación e Información, 23(1), 43-52. http://doi.org/10.35742/rcci.2018.23(1),43-52.

Boccardi, F., Orellana, M., Giovannini, S., \& Rocchietti, D. (2008). El sueño minero: un análisis de la narrativa utópica del desarrollo. Perspectivas de la Comunicación, 1(1), 5672. http://revistas.ufro.cl/ojs/index.php/perspectivas/article/view/10

Cáceres, M.; Ruiz-San-Román, J., \& Brändler, G. (2009). Comunicación interpersonal y vida cotidiana. La presentación de la identidad de los jóvenes en Internet. CIC. Cuadernos de Información y Comunicación, 14, 213-231.

Calderón, C., López, M., \& Pena, J. (2017). El efecto condicional indirecto de la expectativa de rendimiento en el uso de Facebook, Google+, Instagram y Twitter por jóvenes. Revista Latina de Comunicación Social, 72, 590-607. http://doi.org/10.4185/RLCS-2017-1181

Caldevilla-Domínguez, D., Barrientos-Báez, A., \& Parra López, E. (2020). Horizontes del mundo digital: de la simulación y la banalización de la experiencia, a un uso social, ecológico e innovador de la Sociedad Red. CIC. Cuadernos de Información y Comunicación, 25, 269-277. https://doi.org/10.5209/ciyc.68722

Caldevilla-Domínguez, D., García, E., \& Barrientos-Báez, A. (2019). La importancia del turismo cultural como medio de dignificación del turista y de la industria. Mediaciones Sociales, 18, 59-69. https://doi.org/10.5209/meso.65117 
Correyero Ruiz, B. (2003). La propaganda turística española en los años del aislamiento internacional. Historia y Comunicación Social, 8, 47-61. https://revistas.ucm.es/index.php/HICS/article/view/HICS0303110047A

Chinchay-Villarreyes, S., Cango Córdova, J., Aldana Tume, A., \& Seminario Sanz, R. (2020). Estrategias de promoción para el fomento del turismo religioso en Perú. Revista de Ciencias Sociales, 26(3), 272-283.

Fernández-Cavia, J., Vinyals-Mirabent, S., Fernández-Planells, A., Weber, W., \& PedrazaJiménez, R. (2020). Tourist information sources at different stages of the travel experience. El Profesional de la Información, 29(2), e290219. https://doi.org/10.3145/epi.2020.mar.19

Fiorello, A. (2010). Micro-cluster y nuevo turista. Revista de Comunicación de la SEECI, 23, 1-29. doi: https://doi.org/10.15198/seeci.2010.23.1-29

Fung, T. (2003). El estado del arte de la ciencia política. La Habana: Editorial Félix Varela.

Fung, T. (2004). Una ciencia política desde el Sur. La Habana: Editorial Félix Varela.

Fung, T. (2006). Filosofía política y ciencia política. La Habana: Editorial Félix Varela.

Ganga-Contreras, F., Navarrete-Andrade, E., \& Suárez-Amaya, W. (2017). Aproximación-los fundamentos teóricos de liderazgo auténtico. Revista Venezolana de Gerencia, 22(77), 36-55. https://bit.ly/3wIwH9F

Goeldner, C. (2000). Tourism: Principles, Practices, Philosophies. Toronot: John Wiley \& Sons.

Gómez, R. G. (1990). Teoría de las relaciones políticas internacionales. La Habana: Editorial Pueblo y Educación.

Gonzálvez-Vallés, J., Barrientos-Báez, A., \& Parra-López, E. (2020). Gobernanza y comunicación en la Universidad. Estudio-partir del covid-19. Revista Venezolana de Gerencia, 25(91), 1247-1261. https://produccioncientificaluz.org/index.php/rvg/article/view/33200/34863

Hays, S., Page, S., \& Buhalis, D. (2012). Social Media as a Destination Marketing Tool: its use by National Tourism Organizations. Current Issues in Tourism, 16, 1-29. http://doi.org/10.1080/13683500.2012.662215

Infante-Limón, E. (2014). Guerra, Historia, turismo y prensa: bases de la puesta en valor del patrimonio cultural de Niebla (Huelva) durante el franquismo. Historia y Comunicación Social, 19, 153-170. https://doi.org/10.5209/rev_HICS.2014.v19.47290

Kirk, J. (2007). Toward an Understanding of the Tourism Potential in Cuba. Cornell Hotel \& Restaurant Administration Quarterly, 48(4), 416-418.

Krapf, K., \& Hunziker, W. (1942). Allgemeine Fremdenverkehrslehre. Zurich: Polygraphischer Verlag.

Lim, C., \& Cooper, C. (2009). Beyond Sustainability: Optimising Island Tourism Development. International Journal of Tourism Research, 11(1), 89-103.

Martín-Antoranz, P., Cabezuelo-Lorenzo, F., \& Bartolomé-Muñoz-de-Luna, Á. (2019). Competencias y formación ética de los profesionales de la comunicación corporativa en 
contextos interculturales. Revista de Ciencias de la Comunicación e Información, 24(1), 59-72. https://doi.org/10.35742/rcci.2019.24(1).59-72

Martínez-Valerio, L. (2015). Conocer la personalidad de los universitarios a través de los "me gusta" de Facebook. Prisma Social: revista de ciencias sociales, 15, 147-179.

Matassi, M., \& Boczkowski, P. (2020). Redes sociales en Iberoamérica. Artículo de revisión. El Profesional de la Información, 29(1), e290104. https://doi.org/10.3145/epi.2020.ene.04

Navarro Celis, F., Almaguer Covarrubias, R., Moreno Velazco, F., \& Hernández Rocha, N. (2020). Estrategias comunicacionales en el sector turismo. Revista de Ciencias Sociales, 26(1), 77-90. https://bit.ly/3dL4ab4

Oliveira, A., Correia, A., \& Fernandes, C. (2017). A utilização das redes sociais na perspetiva das empresas de turismo em espaço rural. Pasos. Revista de Turismo y Patrimonio Cultural, 15, 807-822. http://doi.org/10.25145/j.pasos.2017.15.055

OMT (1991). Conferencia Internacional sobre las Estadísticas de Viajes y Turismo. Ottawa: OMT.

Parra, P., Gordo-López, A., \& D’Antonio-Maceiras, S. (2014). La investigación social aplicada en redes sociales. Una innovación metodológica para el análisis de los «Me gusta» en Facebook. Revista Latina de Comunicación Social, 69, 195-212. http://doi.org/10.4185/RLCS-2014-1008

Richter, L. (1983). Tourism Politics and Political Science: a Case of not so Benign Neglect. Annals of Tourism Research, 10(3), 313-335.

Rodríguez-Torres, S., \& Puerta-Rodríguez, H. (s.f.). Economía Internacional. La Habana: Universidad de La Habana.

Sarmiento Guede, J., \& Rodríguez Terceño, J. (2018). La comunicación de boca en boca electrónica en los medios sociales. Análisis de sus antecedentes. Revista de Comunicación de la SEECI, 45, 129-145. http://doi.org.10.15198/seeci.2018.45.129-148

Taylor, H., \& Greenough McGlynn, L. (2009). International Tourism in Cuba: Can Capitalism be Used to Save Socialism? Futures, 41, 405-413.

Torres Bernier, E. (2004). Del turismo en la política económica a la política económica del turismo. Cuadernos de Política Económica, 7, 50-71.

Tribe, J. (1997). The Indiscipline of Tourism. Annals of Tourism Research, 24(3), 638657. 